\title{
The extirpation of large mammals and implications for montane forest conservation: the case of the Kilum-ljim Forest, North-west Province, Cameroon
}

\author{
F. Maisels, E. Keming, M. Kemei and C. Toh
}

\begin{abstract}
A review was carried out of the mammalian fauna of the Kilum-Ijim forest in the mountains of northwest Cameroon. The purpose was to examine the loss of species, particularly of larger mammals, and the implications of this for forest ecology. Information was collected by direct observation, hunter interviews and a literature review. The forest is the largest remaining representative fragment of the West African montane forest habitat. Seventy-seven species of mammal have been recorded in the forest over the last 50 years. Most are small, especially rodents, bats and insectivores. Seven species are endemic to the Kilum-Ijim area. The process of species extirpation probably began over 100 years ago with the loss of the mega-fauna, possibly beginning with elephant Loxodonta africana (several generations ago), and certainly with buffalo Syncerus caffer (at least 20 years ago), and other large mammals. Remaining large mammal population densities are very low and many species are close to regional extinction. The long-term consequences of these extinctions is
\end{abstract}

uncertain but, as many tree species are monkey- or ruminant-dispersed, severe ecosystem damage has probably already occurred. Human population density in the area is around 300 people per sq $\mathrm{km}$, and no sustainable offtake of wild animals will ever be possible that would provide more than a few grams of meat per person per year from the forest. The protein requirements of the communities of the area will have to continue to be supplied from domesticated stock. Since 1987 the Kilum-Ijim Forest Project of BirdLife International has been working to conserve the remaining forest, using a community forestry approach in collaboration with traditional and local authorities and the government of Cameroon. The project is investigating ways to improve the production of domestic animals outside the forest boundary.

Keywords Bushmeat, Cameroon, extirpation, KilumIjim Forest, mammals, montane forest, seed dispersal.

\section{Introduction}

The montane forests of the Cameroon highlands region are considered to be a priority area for conservation on a global scale (Stuart, 1986; Thomas, 1986; Collar \& Stuart, 1988; Bibby et al., 1992; Stattersfield et al., 1998), and are one of the most important centres of endemism on the African continent (Stuart, 1986; Bibby et al., 1992; Stattersfield et al., 1998). A relatively well-studied area within the Cameroon Highlands is the Kilum-Ijim forest on the massif of Mount Oku and its foothills down to an altitude of c. $200 \mathrm{~m}$ (Fig. 1). This is the largest area of montane forest remaining in West Africa.

\footnotetext{
F. Maisels (Corresponding author) Kilum-ljim Forest Project, BirdLife International, PO Box 119, Kumbo, Cameroon. E-mail: bomassa@ uuplus.com. Present address: International Office, Africa Section, Wildlife Conservation Society/New York Zoological Society, 185th Street, Southern Boulevard, Bronx, NY 10460-1099, USA
}

E. Keming, M. Kemei and C. Toh Kilum-ljim Forest Project, BirdLife International, PO Box 119, Kumbo, Cameroon

Revised manuscript accepted for publication 12 July 2001
The Kilum-Ijim forest covers $200 \mathrm{sq} \mathrm{km}$, of which about half is montane forest and the rest degraded montane grasslands, various types of scrubland, and a small area of Afro-subalpine grassland of high conservation importance at the summit of Mount Oku (also known as Mount Kilum) (Letouzey, 1985; Thomas, 1986, 1987; ENGREF, 1987; Macleod, 1987; Tame \& Asonganyi, 1995; Maisels \& Forboseh, 1997; Maisels, 1998; Maisels et al., 1999). The forest occurs above $2000 \mathrm{~m}$ up to a maximum altitude of $3000 \mathrm{~m}$; forests of the lower altitudes have already been cleared for agriculture or for grazing land. Human pressure on the area is intense. There are about 300,000 people living within a day's walk of the Kilum-Ijim forest, and estimates of population density are c. 300 people per sq $\mathrm{km}$ (Kilum-Ijim project, unpublished data).

Since 1987 the Kilum-Ijim Forest Project of BirdLife International has been working to conserve the remaining forest, using a community forestry approach in collaboration with traditional authorities and the government (McKay \& Young, 1995; Nurse et al., 1995a, b; Thomas et al., 1998; Penn \& Gardner, 1999). The main 


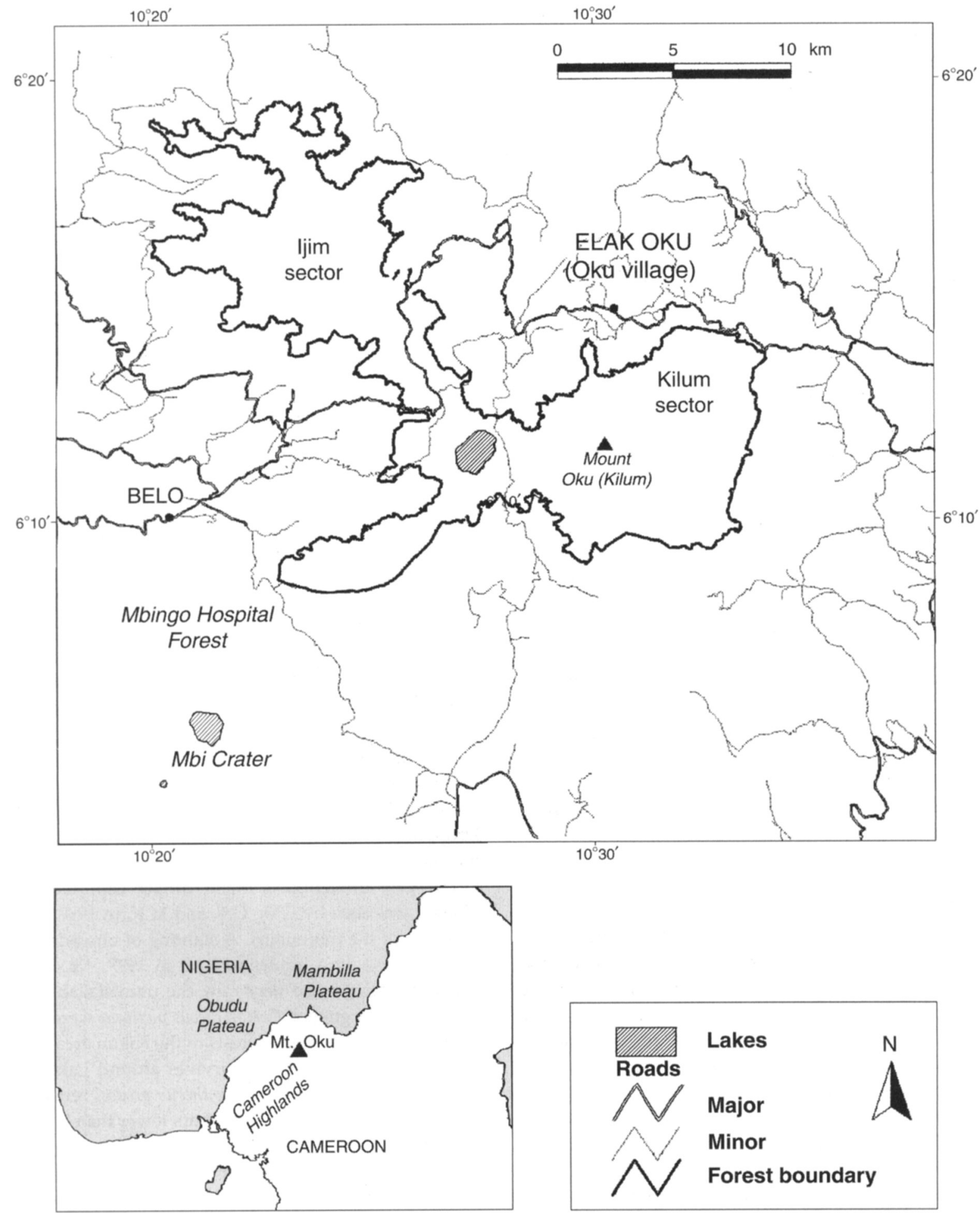

Fig. 1 The Kilum-ljim Forest and Mount Oku, and their position within the north-west Province of Cameroon. 
aim of this paper is to examine the loss of species over time in the Kilum-Ijim Forest, particularly the larger mammals, and the long-term implications of this for the ecology and conservation of the forest.

\section{Methods}

F.M. was living in the village of Elak Oku and frequently staying in the Ijim area for 2 years (March 1997-March 1999). This allowed an atmosphere of trust to be built up with the community. E.K., M.K. and C.T. are local people who have lived in the area all their lives, and E.K. and M.K. were very experienced hunters before their employment as field assistants by the Project in 1989 and 1993, respectively.

Older people, especially hunters or ex-hunters, were engaged in conversation whenever possible over the 2-year period, and the types of animals seen then and in the past were discussed. A total of 35 people from over 20 villages around the massif, usually those who were considered to be the best hunters of the village, were interviewed semi-formally. People were encouraged to imitate monkey calls, and to describe animal's habits, as well as their appearance. Skins of animals seen in people's houses were examined and the place where they were killed, if known, identified.

In addition a review of the literature was carried out, to which our observations were added in order to update and expand the available knowledge of the mammals of the region (von Eisentraut, 1968; Bowden, 1986a, b; Fedden \& Macleod, 1986; Hutterer \& Fulling, 1994). All of the data for rodents and shrews come from Hutterer \& Fulling (1994).

\section{Results}

A total of 77 species of mammal have been recorded in the Kilum-Ijim area (Table 1), mostly small-bodied species of Insectivora, Chiroptera and Rodentia. Of the larger mammals, the last recorded lion Panthera leo in the Ijim area was killed in 1948 (one of the hunters interviewed, now over 70-year-old, helped to carry it to the village). The leopard Panthera pardus is still rumoured to occur but no sightings have been made for at least 20 years. Local tradition requires the skin of any leopard killed in the chiefdom to be given to the fon (the paramount chief), but this was not known to have occurred in the last 20 years either. The last chimpanzee Pan troglodytes was killed in 1987 or 1988 on the eastern side of the forest, although there are rumours of their continued existence to the north of the massif. Hutterer \& Fulling (1994) observed black and white colobus Colobus guereza, but by the late 1990s they had been completely hunted out and the only remaining evidence of the species were the skins that we saw in several houses and occasionally in traditional rituals. The last buffalo Syncerus caffer was seen over 20 years ago (one was killed in Oku village by the father of E.K. in the mid 1970s).

One species not listed in Table 1 is the elephant Loxodonta africana. This animal features strongly in the culture of north-west Cameroon, and stylised representations of elephants are very common as traditional dance masks. The fon of an area often sits with his feet on an ancient elephant tusk, and we saw this on two occasions. None of the older people questioned remembered either their parents or grandparents talking about elephants in the Kilum-Ijim region. Thus we estimate that elephants must have been hunted out of the region more than 100 years ago. The paths that are today used by the human population to travel over the mountains are said by local people to be old elephant trails. All these paths run up ridges and are the easiest routes in this extremely precipitous region. It is of course possible that the 'elephant culture' of the north-west may have come from elsewhere. However, elephants still occur in surrounding, less densely populated areas: in Korup National Park and Banyang Mbo to the south-west (AESG, 1993), the Santchou Reserve to the south (Tchamba \& Seme, 1993), and the Takamanda area to the west (Groves \& Maisels, 1999), all of which include some mountainous forest areas. Thus it seems likely that elephants also occurred in the Cameroon Highlands before the rich volcanic soils attracted high human population densities.

All wild ungulate species are very rare in the forest. Droppings of medium sized duikers were seen by F.M. on only two occasions, both on the Kilum side of the forest. One unidentified infant duiker captured by a villager was seen by F.M., C.T. and M.K. in 1997 on the Ijim side of the mountains. A sighting of one bushbuck was reported by a hunter to F.M. in 1997. All diurnal primates are likewise very rare: the unmistakable calls of putty-nosed guenon Cercopithecus nictitans were heard by F.M. four times in the forests of the Kilum area, and a troop, also heard by F.M., survives around Lake Oku. Some Preuss's guenons Cercopithecus preussi remain on the Kilum side (seen by the authors fewer than 10 times in 2 years). There were still a number of Preuss's guenon in the early 1990s sufficient for their behavioural ecology to be studied (Beeson et al., 1996), but their numbers have since fallen. A troop of about 15 baboons Papio anubis survive at the summit of Mount Oku, seen on three occasions by F.M.

Red river hog Potamochoertus porcus was reported by hunters to be present in the forests of the northernmost extremity of the massif, and dung from the species was seen by all authors when we surveyed a forest reserve 


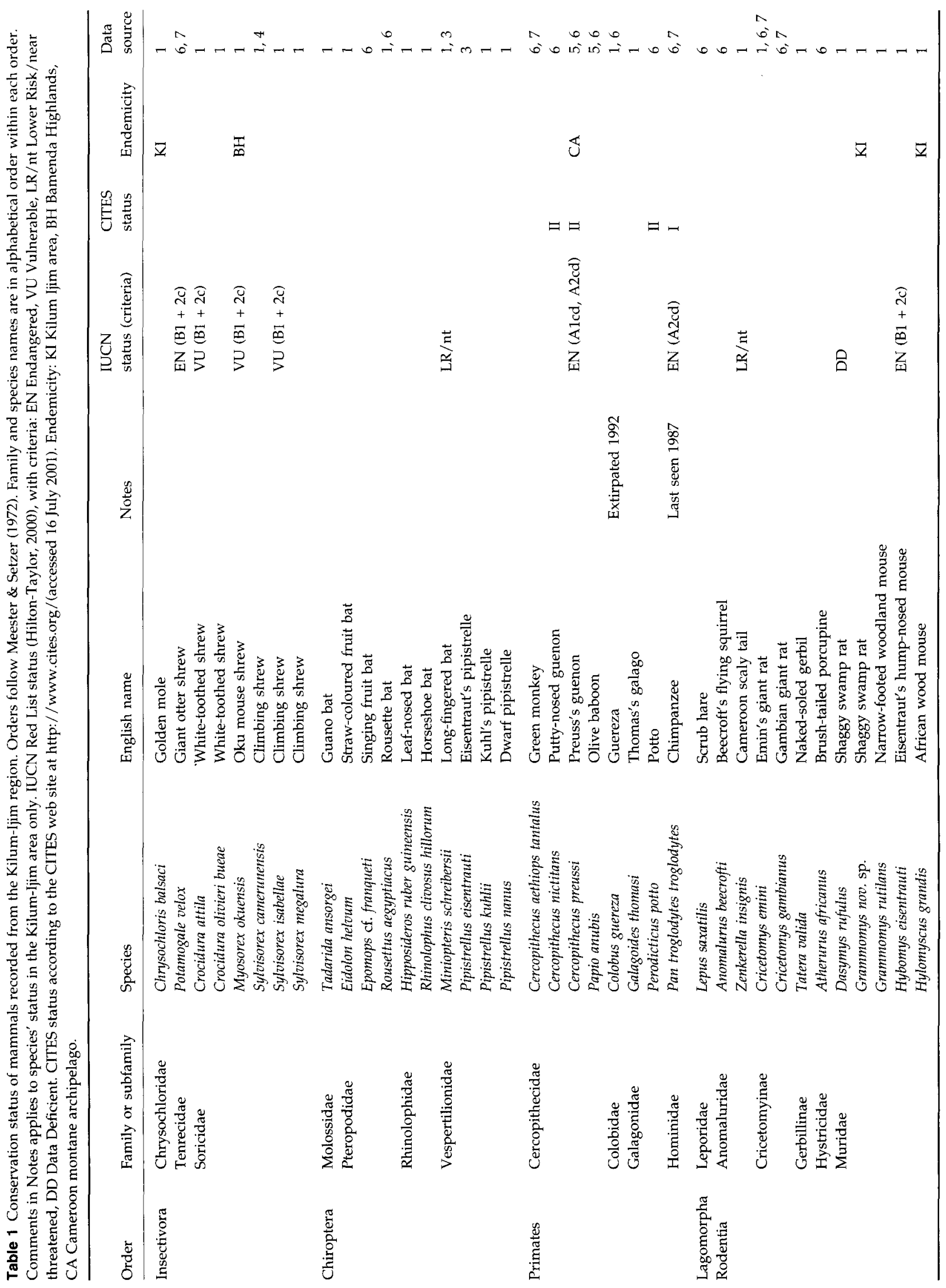

(c) $2001 \mathrm{FFI}$, Oryx, 35(4), 322-331 


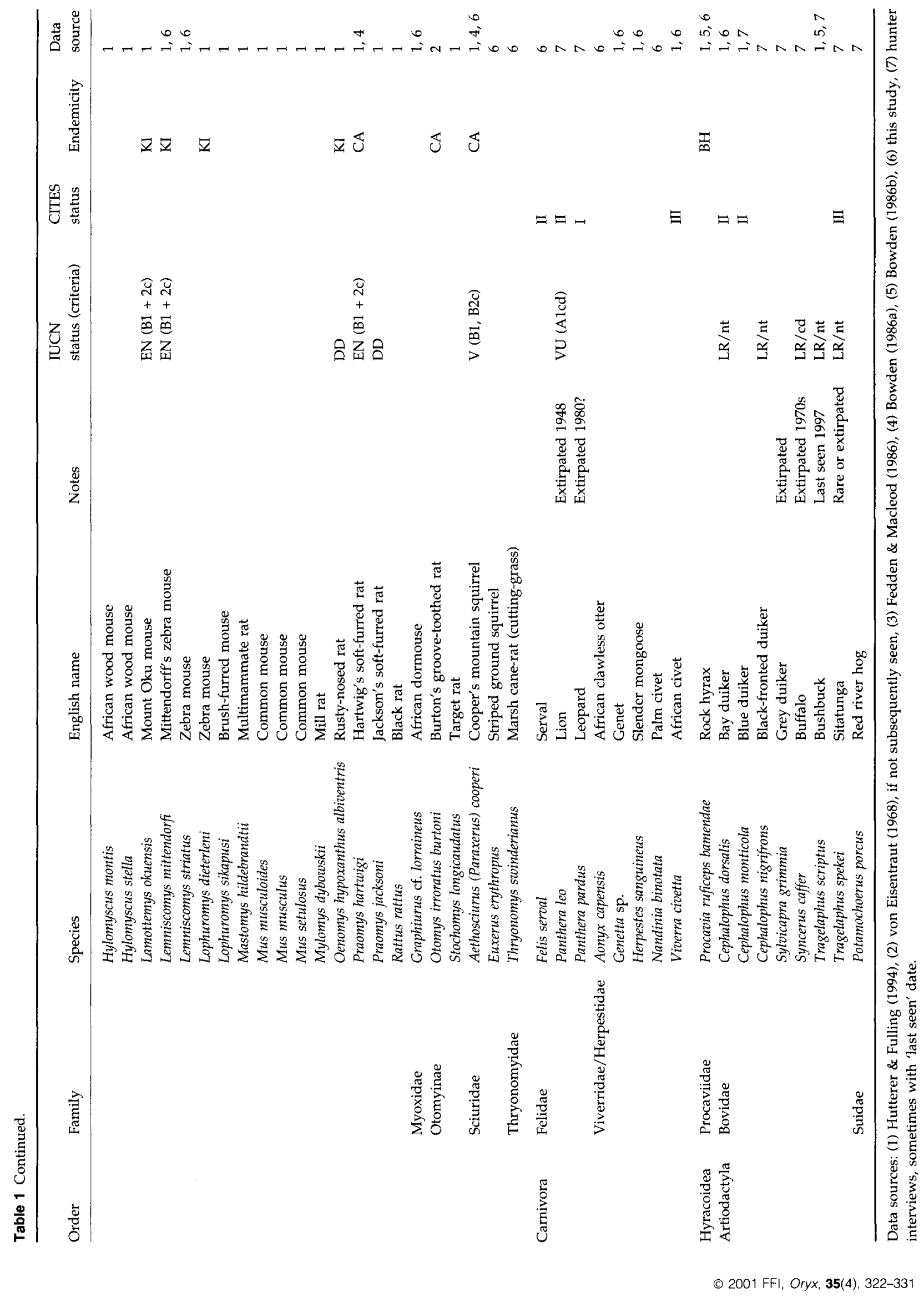


(Mbi Crater, about $1.7 \mathrm{sq} \mathrm{km}$ of undisturbed habitat) just to the south-west of the Ijim forest, and a neighbouring small forest, Mbingo Hospital Forest (about $4 \mathrm{sq} \mathrm{km}$ of which is relatively undisturbed). These two sites shelter small populations of otter Aonyx capensis (tracks seen by the authors), sitatunga Tragelaphus spekei (reported by the Head Warden of the Forest Reserve), putty-nosed guenon, Preuss's guenon (both heard by the authors during the survey) and one or more species of duiker Cephalophus spp. (droppings seen by F.M. and E.K.), chiefly because there has been very little hunting at either site. This is, in the case of Mbi Crater, because of its reputation as a sacred or haunted site, and in the case of Mbingo, due to its status as private land.

The smaller carnivores (genets Genetta spp., slender mongoose Herpestes sanguineus, serval Felis serval, and civet Viverra civetta) are probably still present according to the hunters interviewed. Although we saw skins of these species at most traditional ceremonies, we did not see any fresh skins. No data exists on the abundance of these species, nor on the abundance of any of the nocturnal mammals or of the rodents, although the latter are still trapped throughout the forest.

Seven mammal species are endemic to the massif of Mount Oku including a golden mole Chrysochloris balsaci (that we saw in the north of the massif) and six species of mice (Hutterer \& Fulling, 1994; Table 1). Other mammals within the forest are endemic to the Cameroon mountain chain and include a shrew Myosorex okuensis, and two relatively larger-bodied species: the forest-dwelling Cooper's mountain squirrel Paraxerus cooperi, and Preuss's guenon. Cooper's mountain squirrel is entirely confined to the montane forests and does not occur in scrub or grassland vegetation types (Forboseh \& Maisels, 1999a). Other species endemic to the mountain chain include three species of rat, and two species of shrew (Bowden, 1986a; Nikolaus \& Dowsett, 1989; Hutterer \& Fulling, 1994; Table 1). Pipistrellus eisentrauti was previously thought to be endemic to the mountains of West Africa, but it has since been reported from Ivory Coast and Kenya (Corbet \& Hill, 1986).

Most mammals are considered edible by the local people and many species are also used locally for medicine or for ceremonies. Larger-bodied animals such as primates and duikers were preferentially targeted by hunters in the past, but the high human density has resulted in the removal from the forest of most mammals weighing over $200 \mathrm{~g}$. The only diurnal mammal over $200 \mathrm{~g}$ still frequently seen is Cooper's mountain squirrel (Forboseh \& Maisels, 1999). Present hunting methods target rodents: vertical-loop wire or nylon snares and wooden 'rat-squashing' traps were extremely common in the forest in 1997, with 1.6-4.0 snares and
6.0 'rat-squashing' traps per $\mathrm{km}$ of trail (Maisels \& Forboseh, 1999a). Casual conversations with hunters revealed that one hunter could have as many as 200 'rat-squashing' traps out at one time, but may harvest only 5-10 rodents on each visit.

A survey by the Kilum-Ijim project in 1999 suggested that most people had given up hunting because of the poor rates of return, although it still occurred occasionally (Kilum-Ijim Project, 1999; D. Thomas, pers. comm.). There are about 300,000 people living within a day's walk of the forest (Kilum-Ijim project, unpublished data). Of these about half are adults, and even if only 0.5 per cent of men (women do not hunt in the area) still hunt, that can be up to 375 hunters using $200 \mathrm{sq} \mathrm{km}$ of the area within the forest boundary. If each hunter has 200 traps, this would result in about 75,000 traps, following the reasoning above.

\section{Discussion}

The geographically closest habitat that is similar to the Kilum-Ijim Forest is the Obudu Plateau and its flanks in neighbouring Nigeria, where a survey of the area in the late 1980s and early 1990s recorded gorillas Gorilla gorilla and other montane species (e.g. Harris et al., 1987; Harcourt et al., 1989a, b; Oates et al., 1990). Gorillas still occur in the area (Sarmiento \& Oates, 1999) and in the Takamanda mountains about $90 \mathrm{~km}$ west of Kilum-Ijim (Groves \& Maisels, 1999). However, although the gorilla may have occurred in the Kilum-Ijim area in the past there are no records of it having done so, and the majority of the larger mammals for which there are records from Kilum-Ijim (Table 1) have either been extirpated locally or are rare.

The loss of the larger species of mammals has markedly reduced the biomass of bushmeat available to the local populace, and may also have long-term effects on the ecology of the forest. At present over 80 per cent of tree species occurring in the forest are adapted for animal dispersal and, of these, 97.5 per cent are dispersed by birds or monkeys and 2.4 per cent by rodents (Maisels \& Forboseh, 1999b). Only 20 per cent of the tree species are wind-dispersed (Maisels \& Forboseh, 1999b). Most of the small to medium-sized bird species present in the Afromontane forests can swallow fruits of up to about 10$12 \mathrm{~mm}$ in diameter (Dowsett-Lemaire, 1988), and thus most of the tree species found today in the Kilum-Ijim forest can be bird-dispersed, with two main exceptions.

The first of these is the large Myrtaceous tree Syzygium guineense. This tree has large-seeded $(1.5-2 \mathrm{~cm})$ fruits, the fleshy exterior of which is eaten by many bird species (Dowsett-Lemaire, 1988; 
pers. obs.). It seems likely that only turacos Tauraco bannermani and $T$. persa, and pigeons such as Cameroon olive pigeon Columba sjostetdi and green pigeon Treron australis would actually be able to ingest the seed and carry it from the parent tree. The great blue turaco Corythaeola cristata occurred within the Kilum-Ijim forest until about 10 years ago, but has been hunted out. Because of their flexible mandible tissues, both pigeons and turacos can swallow fruits bigger than their gape (Dowsett-Lemaire, 1988) and so would be good dispersers for Syzygium. However, some Columba species have gizzards that destroy seeds rather than allowing them to pass through the gut (Grubb, 1998). Other birds that normally disperse large-seeded fruits are hornbills (Whitney et al., 1998), but there are no hornbills in the Kilum-ljim forest, nor any cultural evidence that they existed in the past. Primates would also normally disperse this and other Syzygium species (Dowsett-Lemaire, 1988; Kaplin et al., 1998), but few individual monkeys remain in Kilum-Ijim and chimpanzees were hunted out at the same time as the great blue turaco.

The second exception is Carapa grandiflora, which has large, woody capsules and large $(>3 \mathrm{~cm}$ ) oily seeds. These seeds are now mainly dispersed by rodents, which are normally seed predators. Larger seeds may be more often cached by rodents than smaller seeds (Forget et al., 1998), and thus cached seeds that have been 'forgotten' by rodents can germinate. Although it seems possible, from the 'fruit syndrome' (sensu Gautier-Hion et al., 1985) shown by this species, that Carapa may be more of a ruminant or even an elephant-dispersed species, we have seen Carapa seedlings throughout the forest.

Tree species that depend solely on elephants or apes for dispersal appear to be absent from the Kilum-Ijim forest. An example of a species that may formerly have occurred in the area is Balanites wilsoniana. This species, which occurs from Ivory coast to East Africa, including the submontane forests of Kibale in Uganda (Chapman et al., 1992) but not in the Kilum-Ijim forest, is thought to be exclusively dispersed by elephants. $B$. wilsoniana was identified by Hawthorne \& Parren (2000) as being one that would be affected, on a centennial scale, by the absence of forest elephants in the Upper Guinean forests. The consequences of the removal of the largebodied seed dispersers may be far reaching and may well have already resulted in major ecosystem change following the removal of, firstly the elephants, and more recently, most of the other large-bodied mammals. An understanding of the relationships between the large mammals and the tree species in the threatened forest of Kilum-Ijim is of importance for the future longterm conservation of both this and other important montane forest sites in the region, such as Mount Cameroon.

A dense cover of herbaceous species of Acanthaceae and Labiatae beneath which there is little light penetration is a phenomenon apparently confined to some African montane forests (Letouzey, 1985). In the KilumIjim forest a dense cover that includes Mimulopsis solmsii, Brillantaisia spp. and Acanthopale sp. flowers synchronously and dies in a cycle of 7-12 years (Thomas, 1989). A similar 'carpet' of the tall herb Sericostachys scandens covers the ground in montane forests of Nyungwe, Rwanda. Elephants have almost vanished from Nyungwe, and tree seedling regeneration has been consequently suppressed (E.A. Williamson, pers. comm.). Elephants would characteristically have created light gaps in this herb layer during feeding, but in their absence tree seedlings can only regenerate following the synchronous flowering and death of the herb layer. The extirpation of elephants in Kilum-Ijim may thus have caused a change in forest composition.

In most humid tropical forests, protein requirements of local communities are partly or even almost entirely provided by wild animals, and these may be mammals, birds, fish or insects depending on the relationship between the human and animal population densities (Wilkie et al., 1998a, b; Bowen-Jones \& Pendry, 1999; Robinson et al., 1999; Robinson \& Bennett, 2000). In tropical forests, the carrying capacity for people depending exclusively on wild meat cannot greatly exceed one person per sq $\mathrm{km}$ (Bennett \& Robinson, $2000 a, b)$, so clearly any use of wildlife for meat by the populations of the Kilum-Ijim area (300 people per sq $\mathrm{km}$ ) is unsustainable. The conservation of the KilumIjim forest is now under joint management by the Kilum-Ijim Forest Project, the Government, and the local communities. Recent discussions with village councils have shown that people are willing to suspend all hunting within their forest areas for several years in order to allow wildlife populations to recover. For now, the conservation objectives of the project include the recovery of the mammal populations of the area (Maisels, 1998) by continuing collaborative work with local communities and the government. However, with the present levels of high human population density and the corresponding low levels of mammalian density in the forests, no sustainable levels of offtake will ever be possible that would provide more than a few grams of wild meat per person per year from the forest. The protein requirements of the communities of the area will have to continue to be supplied from domestic livestock, and there is a need for this to be clearly explained to local people as part of the environmental education activities of the Project. Finally, ways to improve the 
production of domestic animals around the forest are being investigated, again with the continued collaboration of the local communities.

\section{Acknowledgements}

The Kilum-Ijim Forest Project is a joint programme of BirdLife International and the Ministry of Environment and Forestry of Cameroon. During the time that the work for this paper was carried out, the project was funded by the Global Environment Facility, the British Department for International Development, and the Dutch Ministry of Foreign Affairs/Development. We would like to thank all the staff of the Kilum-Ijim Forest Project, for their help with logistics, their helpful discussions and their good team spirit and friendship, and the Kom, Oku, Nsoh and Fulani people who welcomed F.M. into their communities for 2 years. Thanks to Chris Bowden, David Thomas, Liz Rogers and Liz Williamson for suggesting improvements to the manuscript, and to John Oates and Paul Scholte for their comments during the review process. This paper is dedicated to the memory of Moses Kemei, one of the authors, who very sadly passed away in late 2000. Moses gave several years of his life to the conservation of the montane forests that he loved.

\section{References}

AESG (1993) Regional Report Summaries, African elephant specialist group. Pachyderm, 16, 41-43.

Beeson, M., Tame, S., Keming, E. \& Lea, S.E.G. (1996) Food habits of guenons (Cercopithecus spp.) in Afro-montane forest. African Journal of Ecology, 34, 202-210.

Bennett, E.L. \& Robinson, J.G. (2000a) Carrying capacity limits to sustainable hunting in tropical forests. In Hunting for Sustainability in Tropical Forests (eds J.G. Robinson and E.L. Bennett), pp. 13-30. Colombia University Press, New York.

Bennett, E.L. \& Robinson, J.G. (2000b) Hunting of wildlife in tropical forests. Implications for biodiversity and forest peoples. Environment department papers. Biodiversity Studies: impact series, 42.

Bibby, C.J., Collar, N.J., Crosby, M.J., Heath, M.F., Imboden, Ch., Johnson, T.H., Long, A.J., Stattersfield, A.J. \& Thirgood, S. (1992) Putting Biodiversity on the Map: Priority Areas for Global Conservation. International Council for Bird Preservation, Cambridge, UK.

Bowden, C.G.R. (1986a) Small mammal research in western Cameroon. In Conservation of Cameroon Montane Forests (ed. S. Stuart), pp. 196-200. International Council for Bird Preservation, Cambridge, UK.

Bowden, C.G.R. (1986b) Records of other species of mammal from western Cameroon. In Conservation of Cameroon Montane Forests (ed. S. Stuart), pp. 201-203. International Council for Bird Preservation, Cambridge, UK.
Bowen-Jones, E. \& Pendry, S. (1999) The threat to primates and other mammals from the bushmeat trade in Africa, and how this threat could be diminished. Oryx, 33, 233-246.

Chapman, L.J., Chapman, C.A. \& Wrangham, R.W. (1992) Balanites wilsoniana: elephant dependent dispersal? Journal of Tropical Ecology, 8, 275-283.

Collar, N.J. \& Stuart, S.N. (1988) Key Forests for Threatened Birds in Africa. ICBP Monograph no. 3. International Council for Bird Preservation, Cambridge, UK.

Corbet, G.B. \& Hill, J.E. (1986) A World List of Mammalian Species. 2nd edn. British Museum (Natural History), London.

Dowsett-Lemaire, F. (1988) Fruit choice and seed dissemination by birds and mammals in the evergreen forests of upland Malawi. Revue d'Ecologie; la Terre et la Vie, 43, 251-285.

von Eisentraut, M. (1968) Die tiergeographisce Bedeutung des Oku-Gebirges im Bamenda-Banso-Hochland (WestKamerun). Bonner Zoologische Beitraege, 3/4, 170-175.

ENGREF (1987) Massif d'Oku, Cameroon. Classement en reserve et principes pour un plan directeur d'amenagement. Summary. ENGREF, Centre Universitaire de Dschang, Cameroon.

Fedden, M.O. \& Macleod, H.L. (1986) Bat research in western Cameroon. In Conservation of Cameroon Montane Forests (ed. S. Stuart), pp. 175-195. International Council for Bird Preservation, Cambridge, UK.

Forboseh, P. \& Maisels, F. (1999) Habitat Preferences of Common Montane Forest Birds and Cooper's Mountain Squirrel and their relevance as Indicators for Biological Monitoring. Technical Report. Kilum-Ijim Forest Project. BirdLife International, Cambridge, UK and The Ministry of Environment and Forestry, Cameroon.

Forget, F.M., Milleron, T. \& Feer, F. (1998) Patterns in postdispersal seed removal by neotropical rodents and seed fate in relation to seed size. In Dynamics of Tropical Communities, 37th Symposium of the British Ecological Society, Cambridge, 1996 (eds D.M. Newbery, H.H.T. Prins and N.D. Brown), pp. 25-49. Blackwell Science, Oxford.

Gautier-Hion, A., Duplantier, J.-M., Quris, R. et al. (1985) Fruit characters as a basis of fruit choice and seed dispersal in a tropical forest vertebrate community. Oecologia, 65, 324-337.

Groves, J. \& Maisels, F. (1999) The Large Mammal Fauna of the Takamanda Forest Reserve, South West Province, Cameroon, with Special Emphasis on the Gorilla Population. Takamanda Forest Surveys Project, WWF Cameroon, Yaoundé, Cameroon.

Grubb, P.J. (1998) Seeds and fruits of tropical rainforest plants: interpretation of the range in seed size, degree of defence and flesh/seed quotients. In Dynamics of Tropical Communities, 37th Symposium of the British Ecological Society, Cambridge, 1996 (eds D.M. Newbery, H.H.T. Prins and N.D. Brown), pp. 1-24. Blackwell Science, Oxford.

Harcourt, A.H., Stewart, K. \& Inahoro, I. (1989a) Nigeria's gorillas: a survey and recommendations. Primate Conservation, 10, 73-76.

Harcourt, A.H., Stewart, K. \& Inahoro, I. (1989b) Gorilla quest in Nigeria. Oryx, 23, 7-13.

Harris, D., Fay, M.J. \& Macdonald, N. (1987) Report of gorillas from Nigeria. Primate Conservation, 8, 40. 
Hawthorne, W.D. \& Parren, M.P.E. (2000) How important are forest elephants to the survival of woody plant species in Upper Guinean forests? Journal of Tropical Ecology, 16, 133-150.

Hilton-Taylor, C. (compiler) (2000) 2000 Red List of Threatened Species. IUCN, Gland, Switzerland, and Cambridge, UK.

Hutterer, R. \& Fulling, O. (1994) Mammal diversity in the Oku Mountains, Cameroon. In International Symposium on Biodiversity and Systematics in Tropical Ecosystems, p. 33. Museum Koenig, Bonn.

Kaplin, B.A., Munyaligoga, V. \& Moermond, T.C. (1998) The influence of temporal changes in fruit availability on diet composition and seed handling in blue monkeys (Cercopithecus mitis doggetti). Biotropica, 30, 56-71.

Kilum-Ijim Project (1999) Hunting and Bushmeat Survey. Community Forestry Programme. Kilum-Ijim Forest Project. BirdLife International/Ministry of Environment and Forestry, Cambridge, UK and Yaoundé, Cameroon.

Letouzey, R. (1985) Notice de la carte phytogeographique du Cameroun au 1:500,000 (Region Afro-montagnarde et Útage submontagnard). IRA Yaoundé, Cameroun/Institut de la Carte Internationale de la vegetation, Toulouse, France.

Macleod, H. (1987) Conservation of Oku Mountain Forest, Cameroon. ICBP Report no. 15. International Council for Bird Preservation, Cambridge, UK.

Maisels, F. (ed.) (1998) Conservation Objectives. Kilum-Ijim Forest Project. Kilum-Ijim Forest Project, BirdLife International/ Ministry of Environment and Forestry, Cambridge, UK and Yaoundé, Cameroon.

Maisels, F., Cheek, M. \& Wild, C. (1999) Rare plants on Mount Oku summit, Cameroon. Oryx, 34, 136-140.

Maisels, F. \& Forboseh, P. (1997) Vegetation Survey: Ecological Monitoring Programme 1997. Technical Report, Ecomonitoring programme, Kilum-Ijim Forest Project. Kilum-Ijim Forest Project, BirdLife International/Ministry of Environment and Forestry, Cambridge, UK and Yaoundé, Cameroon.

Maisels, F. \& Forboseh, P. (1999a) Methods Manual and Biodiversity List, Kilum-Ijim Forest, Cameroon. Technical Report, Ecomonitoring programme, Kilum-Ijim Forest Project, BirdLife International/Ministry of Environment and Forestry, Cambridge, U.K. and Yaoundé, Cameroon.

Maisels, F. \& Forboseh, P. (1999b) Phenology of the Major Tree and Shrub Species of the Kilum-Ijim Forest. Technical Report, Ecomonitoring programme, Kilum-Ijim Forest Project, BirdLife International/Ministry of Environment and Forestry, Cambridge, U.K. and Yaoundé, Cameroon.

McKay, C.R. \& Young, J. (1995) Developing a Monitoring Programme for Combined Community and Biodiversity Forest Management in the Kilum-ijim Montane Forest, Cameroon. Report to BirdLife International, September 1995.

Meester, J.A.J. \& Setzer, H.W. (1972) Mammals of Africa: an Identification Manual. Smithsonian Institute Press, Washington, DC.

Nikolaus, G. \& Dowsett, R.J. (1989) Small mammals collected in the Gotel mountains and on the Mambilla plateau, eastern Nigeria. In A Preliminary Natural History Survey of Mambilla Plateau and some Lowland Forests of Eastern Nigeria (ed. R. J. Dowsett), 42-47. Tauraco Research Report 1, Turaco Press, Liege, Belgium.
Nurse, M., Irwin, B.C. \& Asanga, C.A. (1995a) Working Guidelines for Community Forestry in the Montane Forests of North West Cameroon. BirdLife International, Cambridge, UK.

Nurse, M.C., McKay, C.R., Young, J.T. \& Asanga, C.A. (1995b) Biodiversity conservation through community forestry in the montane forests of cameroon. ODI Rural Development Forestry Network Paper, 18d, pp. 14-19.

Oates, J.F., White, D., Gadsby, E.L. \& Bisong, P.O. (1990) Conservation of Gorillas and Other Species. Feasibility StudyAppendix I. Interim report. Cross River National Park, Okwango Division, Nigeria.

Penn, N.J. \& Gardner, A. (1999) Government and Nongovernmental Institutional Collaboration in Implementing Community Forestry; the Case of Kilum-ijim Forest Project. Paper presented at the International Workshop on Community Forestry, The Gambia, April, 1999.

Robinson, J.G. \& Bennett, E.L. (eds) (2000) Hunting for Sustainability in Tropical Forests. Columbia University Press, New York.

Robinson, J.G., Redford, K.H. \& Bennett, E.L. (1999) Wildlife harvesting in logged tropical forests. Science, 284, 595-596.

Sarmiento, E.E. \& Oates, J.F. (1999) Cross River Gorillas - a neglected subspecies. Gorilla Journal, 19, 14-16.

Stattersfield, A., Crosby, M., Long, A.J. \& Wege, D.C. (1998) Endemic Bird Areas of the World. Priorities for Biodiversity Conservation. BirdLife International, Cambridge, UK.

Stuart, S.N. (ed.) (1986) The Conservation of the Montane Forests of Western Cameroon. International Council for Bird Preservation, Cambridge, UK.

Tame, S. \& Asonganyi, J. (1995) Vegetation Survey of the Ijim Mountain Forests, Northwest Province, Cameroon. BirdLife International/Global Environment Facility and International/Ministry of Environment and Forestry, Cameroon.

Tchamba, M. \& Seme, P. (1993) Diet and feeding behaviour of the forest elephant in the Santchou Reserve, Cameroon. African Journal of Ecology, 31, 165-171.

Thomas, D.W. (1986) Vegetation in the montane forest of Cameroon. In Conservation of Cameroon Montane Forests, Report of the ICBP Cameroon Montane Forest Survey (ed. S. Stuart), pp. 20-27. International Council for Bird Preservation, Cambridge, UK.

Thomas, D.W. (1987) Vegetation of Mount Oku. In Conservation of Oku Mountain Forest, Cameroon (ed. H. Macleod), pp. 54-56. ICBP Report no. 15, International Council for Bird Preservation, Cambridge, UK.

Thomas, D.W. (1989) Stranglers and Monocarpic Herbs in the Montane Forests of Cameroon. Kilum-ljim Forest Project, BirdLife International/Ministry of Environment and Forestry, Cambridge, UK, and Yaoundé, Cameroon.

Thomas, D.H.L., Gardner, A. \& Demarco, J. (1998) Devolution of Decision-making: Lessons from Community Forestry Management at the Kilum-ijim Forest Project, Cameroon. Paper presented at the Workshop on Participatory Natural Resource Management, Mansfield College, Oxford, April, 1998.

Whitney, K.D., Fogiel, M.K., Lamperti, A.M. et al. (1998) Seed dispersal by Ceratogymna hornbills in the Dja Reserve, Cameroon. Journal of Tropical Ecology, 14, 351-371. 
Wilkie, D.S., Curran, B., Tshombe, R. \& Morelli, G.A. (1998a) Managing bushmeat hunting in Okapi Wildlife Reserve, Democratic Republic of Congo. Oryx, 32, 131-144.

Wilkie, D.S., Sidle, J., Boundzanga, G., Auzel, P. \& Blake, S. (1998b) Defaunation not deforestation: commercial logging and market hunting in northern Congo. In The Impact of Commercial Logging on Wildlife in Tropical Forests (eds A. Grajal, J. Robinson and A. Vedder). Wildlife Conservation Society, Bronx, NY.

\section{Biographical sketches}

F. Maisels has been active in Central African conservation and research projects since 1988 in the forests of Gabon, Congo, Cameroon and the Democratic Republic of Congo. She worked for the Kilum-Ijim Forest Project (BirdLife International) for 2 years as Project Ecologist and Conservation Advisor. Since early 1999 she has been Research Advisor for the Wildlife Conservation Society in the Nouabale-Ndoki National Park, a lowland forest in Northern Congo.

E. Keming and the late M. Kemei were skilled hunters in the Kilum-Ijim area before being recruited as full time field staff by the Kilum-Ijim Project, and turned their considerable expertise to conservation fieldwork. $C$. Toh has also been a field technician with the Kilum-Ijim Forest Project for many years, and came from a background of post A-level language teaching. His education, his interest in the natural world and in conservation in particular have allowed him to become a valuable member of the biological team. 